\title{
Influence of Monetary Policy Variables on Loan Supply to Small and Medium Scale Enterprises in Nigeria
}

\author{
NTO Philips O. O. ${ }^{1}$, Mbanasor Jude. A. ${ }^{1} \&$ Osuala Alex E. ${ }^{1}$ \\ ${ }^{1}$ College of Agribusiness and Financial Management, Michael Okpara University of Agriculture Umudike, Abia \\ State, Nigeria \\ Correspondence: NTO Philips. O. O., College of Agribusiness and Financial Management, Michael Okpara \\ University of Agriculture Umudike, Abia State, Nigeria. E-mail: nto2015@yahoo.com
}

Received: April 16, 2012

Accepted: May 14, $2012 \quad$ Published: July 1, 2012

doi:10.5539/ijef.v4n7p157

URL: http://dx.doi.org/10.5539/ijef.v4n7p157

\begin{abstract}
The study examined the influence of monetary policy variables on banks' credit supply to small and medium scale enterprises (SMEs) in Nigeria. Time series data which were collected on quarterly basis were elicited from the Central Bank of Nigeria (CBN) Statistical bulletin and financial statements for five commercial banks. The data covered a period of 1995-2010 and were analyzed using Fully Modified Least Squares (FMOLS). Considering the time series properties of the variables, unit root test was done with Philips Perron test to establish stationarity prior to actual analysis. The result of the FMOLS indicated that policies on interest rate and liquidity ratio were negatively and positively significant at 1 percent probability level respectively. Based on the results, it was recommended that government through $\mathrm{CBN}$ should strengthen existing policies on the adjustment of interest rates and liquidity ratio so as to increase and stabilize credit supply to SMEs.
\end{abstract}

Keywords: monetary policy, loan, small and medium scale enterprises, co-integration

\section{Introduction}

Small and medium scale enterprises (SMEs) have been recognised by economic policy makers as essential and veritable element in the process of industrialization of both developed and underdeveloped economies. They have significantly played seminal role in building a competitive private sector; providing employment for 70 percent of the population and contributing well over 50 percent to the gross domestic product (Rocha et al., 2011 and Udechukwu 2003).

Nto and Mbanasor (2011) and Anyanwu (2003) noted that SMEs apart from increasing the per capita income and output also help in ensuring food security of poor countries such as Nigeria. Obamuyi (2007), Oyekanmi (2003) and Adelaja (2003) observed that SMEs, despite their roles in promoting economic growth in Nigeria, suffer acute capital formation and are more financially constrained than large firms in sourcing for credit from formal credit institutions such as banks and capital markets. Rocha et al., (2011) supported that despite the increasing interest in the SMEs sector, lending volumes are still not very impressive. They queried how total lending to SMEs in an oil economy could only be 2 percent of banks total credit portfolio. CBN (2005) observed that traditional commercial banks have been experiencing aggregate credit growth to the domestic economy, yet the ratio of loan supply to small-scale enterprises has continued to decrease over the years. This is in spite of mandatory enforcement by the CBN to the commercial banks to increase lending to SMEs. This situation has been of great concern to government thus, has exacerbated concerted efforts and intervention through increased budgetary allocation, credit policy formulations and implementation of new programmes and schemes (Mbanasor and Nto, 2009).

Lemuel (2009), CBN (2009), Udechukwu (2003) and Anyanwu (2003) highlighted that such credit policies and schemes ranged from Mandatory Credit Guideline (1970), Small Scale Industries Credit Guarantee Scheme (1971), Agricultural Credit Guarantee Scheme (1973), Nigeria Agriculture and Co-operative Bank (1973), Nigerian Bank for Commerce and Industry (1973), Rural Banking Scheme (1977), the World Bank Assisted SME I (1985), African Development Bank - Export Stimulation Loan Scheme (ADB-ESL) in 1988 and the World Bank Assisted SME II (1990), Second - Tier Security Market (1985), Peoples Bank (1989), National Economic Reconstruction Fund (1992), Small and Medium Scale Enterprises Loan Scheme (1992), Family Economic Advancement Program (1997), Bank of Industry (BOI) - being merger of NIDB, NBCI and NERFUND) in 2001, Nigerian Agricultural Co-operative and Rural Development Bank (NACRDB) - being merger of NACB, Peoples Bank and Family 
Economic Advancement Program (FEAP) in 2002 to Small and Medium Enterprises Development Agency of Nigeria (SMEDAN) in 2004.

Outside the multiplicity of interventions adduced supra, the CBN has continuously been reviewing monetary policy instruments such as cash reserve ratio (CRR) and liquidity ratio (LR) to ensure availability of credit by the banks. A case in point was the prompt response to the immediate past global financial crises which triggered the reduction of CRR from $4.0 \%$ to $2.0 \%$ on September 18,2008 and subsequently to $1.0 \%$ on April 14, 2009. The aim was to improve liquidity in the banking system which would impact positively on banks' ability to increase credit supply to SMEs and thus, reduce the crippling effect on the crises on Nigerian economy. In a similar vein, (CBN, 2010); Obamuyi, (2007) and Ogujiuba et al., (2004) added that the capitalisation of banks' to N25billion which took effect from January 1, 2006 was expected to make banks maintain high capital adequacy hence minimum of 40 percent liquidity ratio of total deposit. As such, this development increases financial resources at the command of the banks to grant as credit to SMEs.

It is disheartening to note that upon all the special interventions by the Central bank of Nigeria (CBN) to induce banks credit supply to SMEs, the reverse seems the case as evidenced by reports of CBN (2010) that the percentage of total credit to SMEs still fell from $48.8 \%$ in 1992 to $9.0 \%, 8.6 \%$ and $2.7 \%$ in 2000, 2002 and 2005 respectively. A good analogy can also be drawn from the surveys conducted by Aremu and Adeyemi (2011) and Nto and Mbanasor (2009) which opined that more than 77 percent of SMEs in Nigeria do not have access to credit from external finance like banks while all the large firms sampled have access to credit from formal financial institutions.

With this ugly trend in credit supply to SMEs, the question to ask is, whether Nigeria (a rural based economy) still has the hope of becoming one of the leading economies in 2020? Nto and Mbansor (2011) observed that the tendency of reducing poverty in line Millennium Development Goals (MDGs) specification seems an up-hill task given that these small and less privileged firms that are supposed to be important strategy for creating investments and job opportunities for the poor in Nigeria are under nourished in credit supply by formal financial institutions, hence, the need for policy intervention to forestall the financial crisis that may befall the sector.

It is on this premise that this paper intends to examine the influence of monetary policy variables on credit supply to SMEs in Nigeria, the outcomes of which will help government of Nigeria to put policies right in a manner that will help SMEs survive the intense competition arising from globalisation. This is so since finance is necessary to help them set up and expand their operations, develop new products and invest in new staff or production facilities. If this financing cannot be found, brilliant ideas may fall by the wayside and this represents a loss in potential growth for the economy (OECD, 2006)

Useful inspiration was drawn from prior studies but the major line of discrepancy emanated from the fact that the present study had a macroeconomic dimension and employed a model which gives general picture of the situation. The studies include:

Obamuyi (2007) in a study conducted in Ondo State of Nigeria, observed that, the major determinants of loan supply to SMEs are regulatory requirements such as Capital Adequacy Ratio (CAR), Reserve Requirements (RR), Liquidity Ratio (LR), Interest Rate Development (IRD) and lending policies of the banks. These determinants have varied degrees of influence on the amount of money available for lending by the banks but failed to estimate the direction of the influence of identified policy instruments.

Rahji and Apata (2012) in a study on "Understanding the Credit Supply Decisions of Banks under the Small and Medium Enterprises Equity Investment Scheme in Nigeria" found that interest rate was positively related to credit supply to SMEs at $1 \%$ probability level. This implies that increase in interest rate will stimulate savings in banks thus improvement in credit availability to SMEs. The study adopted tobit model in the analysis of cross sectional data, collected from lending banks' staff. The findings of this analysis may be misleading considering that credit supply to SMEs may not respond to short run interest rate changes based on cross sectional data but on long run changes and time series approach.

As a remedy to the above shortcoming, the present study adopted a co-integration regression approach following Lutkepohl (2004) which opined that co-integration analysis is a better concept for modelling equilibrium or long run relations of economic and financial variables.

\section{Methodology}

The study was conducted in Nigeria which is one of the largest countries in Africa with a total geographical area of 923768 square kilometres and an estimated population of over 150 million. It lies wholly within the tropics along the Gulf of Guinea on the western coast of Africa. The country has a highly diversified enterprise system and agro-ecological condition (Nto and Mbanasor, 2011 and Manyong et al., 2005). 
The study employed co-integration regression (using fully modified least squares FMOLS) in the analysis of time series data obtained from CBN statistical bulletin, financial statements of five commercial banks. The data collected for fifteen years on quarterly basis covered 1995-2010 sub-periods.

Empirical research in financial economics is largely based on time series data which have two central properties ie non-stationarity and time varying volatility. Therefore, Philips (1986) reported that regression analysis with variables that contain such properties may produce misleading and spurious results thereby causing biased economic analysis. As such, the following steps were adopted to eliminate the problem.

The first step was the determination of the order of integration (stationarity) of the variables. The unit root test adopted to check whether the time series data were stationary or not was Philips Perron (PP) (Nto and Mbanasor 2011; and Peter and Philips, 1995). PP adopts nonparametric statistical methods to take care of the serial correlation in the error terms without adding lagged difference terms (Gujarati and Sangeetha, 2007). This explains the usage rather than Augmented Dickey-Fuller (ADF) test.

In the second stage, co-integration test was carried out in order to analyse whether the variables were co-integrated or moved jointly in the long run. This was done using parameter instability test following the procedures of Furuoka and Munir (2011); Geda et al.,(2006); Kungi-Vetenskapsakademien ( 2003); Gregory and Hansen (1996); Philips and Hansen (1990).

The last stage was the estimation of their parameters using fully modified least squares (FMOLS) after the number of co-integration relations was established. The superior FMOLS estimator is more reliable to account for serial correlation, potential endogeneity and multicollinearity problems and thus, is preferable to simple OLS.

Some other diagnostic tests (autocorrelation test, Jarque - Bera test etc) were also conducted to determine the presence of autocorrelation. The analyses were done with E-view software programs (Hendry and Juselius 2000; Ezirim and Muoghalu 2006)

Following the above procedures, the dependent variables (credit supply to SMEs) can be expressed as a function of cash reserve ratio; liquidity ratio, interest rate and lending rate of banks in Nigeria. Explicitly, the relationships can be specified as:

$$
\operatorname{LnCSUPP}=\alpha_{0}+\alpha_{1} \operatorname{LnCRR}+\alpha_{2} \operatorname{LnITR}+\alpha_{3}+\operatorname{LnLR}+\alpha_{4} \operatorname{LnLD}+\mathrm{U}_{\text {It. }}
$$

$\left(\alpha_{1}, \alpha_{2}>0\right)$ elasticities.

Where:

$\alpha_{0-4}=$ Parameter to be estimated

CSUPP $_{\mathrm{t}}=$ Credit supply to SMEs by banks that is amount of loans lent to SMEs by bank over the period. (Naira)

$\mathrm{CRR}=$ Cash reserve ratio

$\mathrm{ITR}=$ Prevailing interest rate is that which banks accept deposit from customers (Percent)

$\mathrm{LR}=$ Liquidity ratio

$\mathrm{LD}=$ Lending rate is that which banks grant credits to SMEs (Percent)

$\mathrm{U}_{\mathrm{it}}=$ Error term

$\mathrm{Ln}=$ Natural Logarithm applicable to each variables.

\section{Results and Discussion}

The results followed a systematic time series econometric approach to examine the influence of monetary policy variables on credit supply to SMEs in Nigeria. The results of unit root using Philips-Perron (PP) test are presented in Table I. From the Table 1, some of the variables: Credit supply (CSUPP), Cash reserve ratio (CRR), and interest rate (ITR) were non stationary at their level form and thus cannot be deemed to be integrated of order zero i.e. 1(0). 
Table 1. Results of unit root test

\begin{tabular}{lllll}
\hline Variable & $\begin{array}{l}\text { Level Form } \\
\text { T-statistics }\end{array}$ & P-value & $\begin{array}{c}1^{\text {st }} \text { Difference } \\
\text { T-statistics }\end{array}$ & P-value \\
\hline Constant & $-2.860611^{* *}$ & 0.0644 & $-2.881370 * *$ & 0.0084 \\
CSUPP & -1.3754 & 0.577 & $-4.430574 * * *$ & 0.0020 \\
CRR & -1.904286 & 0.3250 & $-4.9348 * * *$ & 0.0006 \\
LR & $-3.043719 * * *$ & 0.0444 & $-10.86056 * * *$ & 0.000 \\
LD & $-2.778259 * *$ & 0.0757 & $-7.0782 * * *$ & 0.0000 \\
ITR & -1.884945 & 0.3335 & $-5.5712 * * *$ & 0.0001 \\
\hline
\end{tabular}

$* * *, * *$ and $*$ denotes the level of significant at $1 \%, 5 \%$ and $10 \%$ respectively.

Source: Output from E-Views 7.0 based on CBN data (2010).

The series were further taken to the first difference of the time series, the variables were found to be stationary [ie integrated of order 1(1)]. Following this, the dependent variable (CSUPP) was further regressed on the explanatory variables so as to find the residuals that come from the regression analysis at the level form.

Table 2. Test for unit root in the residual of the level for regression

\begin{tabular}{|c|c|c|c|}
\hline \multicolumn{4}{|c|}{ Null Hypothesis: RES1 has a unit root } \\
\hline \multicolumn{4}{|l|}{ Exogenous: Constant } \\
\hline \multicolumn{4}{|c|}{ Bandwidth: 1 (Newey-West automatic) using Bartlett kermel } \\
\hline \multirow{2}{*}{\multicolumn{2}{|c|}{ Philips-Perron test statistic }} & Adj. t-stat & Prob.* \\
\hline & & -2.650716 & 0.0967 \\
\hline \multirow[t]{3}{*}{ Test critical values } & $1 \%$ level & -3.724070 & \\
\hline & $5 \%$ level & -2.986225 & \\
\hline & $10 \%$ level & -2.632604 & \\
\hline \multicolumn{4}{|c|}{ *MacKinnon (1996) one-sided p-values. } \\
\hline
\end{tabular}

Source: Results from E-Views Package based on CBN Data (2010).

The result of the regression presented in Table 2 indicated that the series were not integrated of order zero i.e. 1(0) at $5 \%$ and below. The t-statistic (-2.651) showed there is existence of a weak relationship and hence cannot be used for further analysis. The series at first difference level gave residuals which were integrated of order one i.e. 1(1) as a result of the t-statistic of the PP (-16.248) which was significant at 1\% probability level as shown in Table 3.

Table 3. Test for unit root in the residuals of the 1st difference

\begin{tabular}{|c|c|c|c|}
\hline $\begin{array}{l}\text { Null Hypothesis: } \mathrm{D}( \\
\text { Exogenous: Constan } \\
\text { Bandwidth: } 21 \text { (New }\end{array}$ & $\begin{array}{l}\text { 1) has a unit root } \\
\text { Nest automatic) u }\end{array}$ & Bartlett ke & \\
\hline \multirow{2}{*}{\multicolumn{2}{|c|}{ Philips-Perron test statistic }} & Adj. t-stat & Prob.* \\
\hline & & -16.24814 & 0.0001 \\
\hline \multirow[t]{3}{*}{ Test critical values: } & $1 \%$ level & -3.737853 & \\
\hline & $5 \%$ level & -2.991878 & \\
\hline & $10 \%$ level & -2.635542 & \\
\hline \multicolumn{4}{|c|}{ *Mackinnon (1996) one-sided p-values. } \\
\hline \multicolumn{2}{|c|}{ Residual variance (no correction) } & \multicolumn{2}{|c|}{1.050635} \\
\hline \multicolumn{2}{|c|}{ HAC corrected variance (Bartlett kernel) } & \multicolumn{2}{|c|}{0.112082} \\
\hline
\end{tabular}

Source: Results from E-Views Package based on CBN Data (2010)

Hence, using the $1 \%$ critical value, the null hypothesis of the unit root for any residual cannot be rejected. Subsequently, co-integration technique was used to confirm the long-run equilibrium relationship among the 
variables (Gujarati and Sangeetha 2007; Nto and Mbanasor, 2011; Johansen and Juselius, (1990) Gregory and Hansen, 1996; Philips and Hansen, 1990). Co-integrating procedure which adopted parameter instability test was used. The result, summarised and presented in Table 4, indicated that the null hypothesis of no co-integration is rejected given the critical value of 0.6808 which was significant at $10 \%$ probability level. This shows that the series tested positive to the co-integration test.

Table 4. Test for co-integration

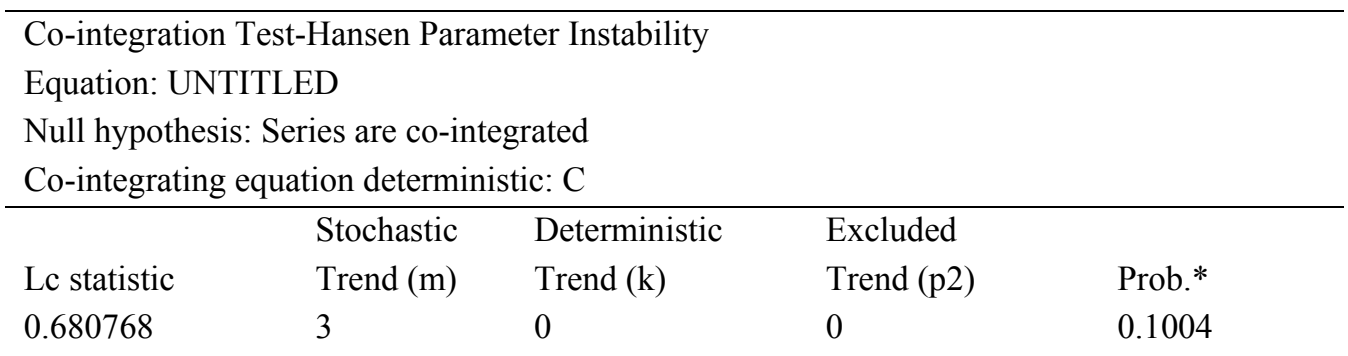

*Hansen $(1992 b)$ Lc $(m 2=3, k=0)$-values, where $m 2=m-p 2$ is the number of stochastic trends in the systematic distribution.

Source: Results from E-Views package based on CBN Data (2010)

Following the above result, it could be implied that there exists a long run equilibrium relationship among the variables. Co-integration regression using fully Modified Least Squares processed with E-Views Software was applied. The results of the regression are summarised and presented in Table 5.

Table 5 indicated that the co-integrating equation used has an intercept with t- statistic of -0.561 in the model and is deterministic. The model has an $\mathrm{R}^{2}$ of 0.34 , implying that $34 \%$ of the variation of the log of credit supply to SMEs was brought about by variation in the independent variables included in the model.

Table 5. Result of cointegration regression

\begin{tabular}{lll}
\hline \multicolumn{3}{l}{ Dependent Variable: CSUPP } \\
\multicolumn{3}{l}{ Method: Fully Modified Least Squares (FMOLS) } \\
\hline Variable & Coefficient & T-Statistic \\
LNCRR & 0.121236 & -0.289453 \\
LNITR & $-4.663617^{* * *}$ & 3.780266 \\
LNLR & $8.714794 * * *$ & 5.162231 \\
LNLD & 1.052101 & -0.341628 \\
Intercept & -1.104808 & -0.561449 \\
R-Square & 0.34 & \\
\hline gnificant at $1 \%, “ * * ”=$ figures Significant at 5\%.
\end{tabular}

NB: “***" = figures Significant at 1\%, “**” = figures Significant at $5 \%$.

Source: Output from E-Views Package based on CBN (2010) data.

The sign of the estimated slope coefficients of the model was negative, implying that the credit supply to SMEs is a decreasing function of the explanatory variables in the model. As such, log credit supply by banks to SMEs in Nigerian economy is on the decrease. This supports CBN (2010) that total credit available for supply to SMEs in Nigeria has been on the decreasing trend from $48.8 \%$ in 1992 to $2.7 \%$ in 2005. Nto and Mbanasor (2011) noted that both large and SMEs felt the sting of poor credit supply between 2007-2009 due to global credit crunch. However, SMEs faced disproportionate declines.

Table 5 further depicted that only two variables were significant namely log of interest rate and log of liquidity ratio. The coefficient of log of interest rate is negatively related to elasticity of credit supply to SMEs and implies that any policy aimed at reducing interest rate will increase credit supply to SMEs by $4.66 \%$. This is contrary to a priori expectation that increase in interest rate should lead to increase in loan portfolio available to the bank to grant as 
credit to SMEs. When interest rate is high, banks and other financial institutions tend to mobilise more savings from depositors, which will in turn increases the lending institutions' credit resources. Low interest rates discourage potential depositors and hence low credit availability and supply to SMEs in the economy. However, Rahji and Apata (2012) had a contrary result implying a positive relationship between interest rate and credit supply to SMEs in Nigeria.

The inverse relationship between interest rate and amount of credit supply to SMEs by commercial banks, obtained in this study may be attributed to other factors (eg. mandatory credit guidelines) which may induce banks to set aside more resources (from their annual profits) to grant as credit to SMEs even when interest rate may not impact on deposit potentials of the credit institutions. Furthermore, liquidity ratio is positively related to credit supply and significant at 1 percent probability level. This finding is in line with conventional view that when liquidity ratio is high, banks will set aside more quantum of resources to grant as credit to SMEs. It is generally expected that when liquidity ratio (i.e. total specified liquid asset/total current liabilities) is high, banks are more liquid, stable and comfortable to handle credit transaction with SMEs. It is under this principle that CBN (2010) and CBN (2009) asserted that the Central Bank of Nigeria has prescribed minimum liquidity ratio of 25.0 percent and has recently increased it to 30.0 percent below which banks cannot operate effectively in Nigeria.

More so, diagnostic tests were conducted on the residuals of the model to validate the model's parameter estimates. Other such tests included are normality of the residual's distribution and presence of serial correlation in the residuals. The results of the test as presented in Table 6 and fig 1 are satisfactory.

Table 6. Q-STATISTICS for autocorrelation test

\begin{tabular}{rrrrrr}
\hline \multicolumn{2}{l}{ Sample: $1995-2010$} & & & & \\
Included observations: 20 & & & & \\
\multicolumn{1}{l}{ Partial } \\
\hline
\end{tabular}

Source: Output from E-Views Package based on CBN (2010) data.

Table 6 examined the presence of $1^{\text {st }}$ order or $2^{\text {nd }}$ order autocorrelation in the model. The test had insignificant Q-stat Values at 0.05 and 0.10 alpha levels which ruled out the threat of autocorrelation in the model. Therefore, the null hypothesis indicating the presence of auto correlation in the error term is accepted.

Figure 1 shows the Jarque-Bera statistic of 0.602 (which was not statistically significant at even 10 percent) and $\mathrm{P}$-Value of $0.7396(\mathrm{P}>0.1)$ while the skewness and kurtosis are -0.0357 and 2.243 respectively, indicating that the sample size and variables are normally distributed for the estimation of the parameters of the model. This follows the assertion of Gujarati and Sangeetha,(2007) that a normally distributed sample size and random variables should have skewness and kurtosis near zero and three respectively. Resultantly, the null hypothesis that the data are not sampled from a normal distribution is therefore rejected. 


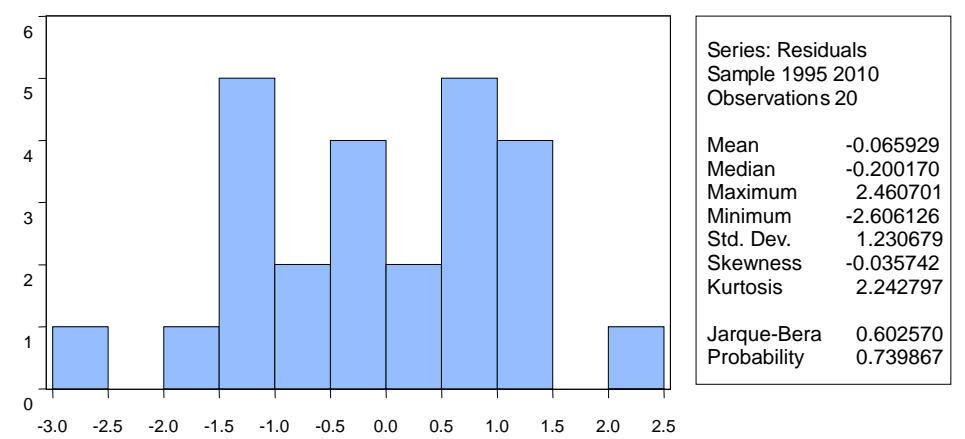

Figure 1. Jarque-Bera Test for normality of the residuals of the cointegration regression model

\section{Conclusion}

Having examined the influence of monetary policy variables on credit supply to small and medium scale enterprises in Nigeria, the results have shown that major determinants of credit supply to SMEs are policies directed on interest rate development and liquidity ratio. The implication is that the interplay of the duo is important to keep SMEs alive in Nigeria. Based on this, it was recommended that CBN should strengthen monetary policies that will adjust interest rate and liquidity ratio in a manner that will increase and stabilize banks' financial resources to enhance credit portfolio to SMEs.

\section{References}

Adelaja B. O. (2003). Financing Small and Medium Enterprises Under SMIEIS;Operators' perspective. Seninar paper on SMIEIS, 4, 95-112. Publication of CBN Training Centre, Lagos.

Anyanwu C. M. (2003). The Role of CBN in Enterprises Financing; Seminar Paper on Small and Medium Industries Equity Investment Scheme. SMIEIS, Publication of CBN Training Centre, Lagos No.4. pp 15-28

Aremu M. A., \& Adeyemi S. L. (2011) SMEs as a Survival Strategy for Employment Generation in Nigeria. Journal of Sustainable Development, 4(1).

Central Bank of Nigeria CBN. (2009). Circular to All Banks in Nigeria: Liquidity and Capital Adequacy Ratio Computation. BSD/DO/CIR/GEN/Vol.02/044.

Central Bank of Nigeria CBN. (2010). Monetary, Credit, Foreign Trade and Exchange Policy Guideline for Fiscal Year 20110/2011. Monetary Policy Circular, No. 38.

Ezirim C. B., \& Muoghalu M. I. (2006). Exchange Rate Determination, Foreign Investment Burden and External Debt Crisis in Less Developed Countries: Nigerian Experience. International Journal of Business and Economics Perspectives, 1(1).

Furuoka F., \& Munir Q. (2011). Can Population Growth Contribute to Economic Development; New Evidence from Singapore. Economics Bulletin, 31(4), 3226-3239.

Geda A., Nudung U. N., \& Zerfu D. (2006). Applied Time Series Econometric: A Focus on Africa. Addis Ababa University and AERC.

Gregory A., \& Hansen B. (1996). Residual Based Tests for Co-integration in Models with Regime Swifts. Journal of Econometrics, 70, 99-126. http://dx.doi.org/10.1016/0304-4076(69)41685-7

Gujarati, D. N., \& Sangeetha. (2007). Basic Econometrics. (4th Ed.), Tata Macgrow-Hill.Companies Inc, New York.

Hansen B. E. (1992). Testing for Parameter Instability in Linear Model. Journal of Policy Modelling, 14(4), 517-533. http://dx.doi.org/10.1016/0161-8938(92)90019-9

Hendry D. F., \& K. Juselius. (2000). Explaining Co-integration Analysis: Part 1. Energy Journal, 21, 1-42. http://dx.doi.org/10.5547/ISSN0195-6574-EJ-Vol21-No1-1

Kungl Vetenskapsakademien. (2003). Time Series Econometrics: Cointegration and Autogrestive Conditional Heteroskedasity. Advance Information on the Bank of Sweden Prize in Economic Sciences in Memory of Alfred Noble, October 8.

Lawal W. A., \& M. A. Ijaiya. (2007). Small and Medium Scale Enterprises' Access to Commercial Banks' Credits and Their Contribution to GDP in Nigeria. Asian Economic Review, 49(3). 
Lemuel E. (2009). Financing Options For Small and Medium Enterprises (SMEs): Exploring Non-Bank Financial Institutions As an Alternative Means of Financing- The Case of Nigeria. School of Management, Blekinge Institute of Technology, Msc Thesis in Business Ad-ministration.

Lutkepohi H. (2004). Recent Advances in Co-integration Analysis. Seminar Paper Presented in Venice University,Italy.

Manyong V. M., A. Ikpi, Olatyemi J. K., Yusuf S. A, Omonona B.T, Okoruwa J. V., \& Idachaba F. S. (2005). Agriculture in Nigeria: Identifying opportunities for Increased commercialisation and investment. Inter-national institute of tropical Agriculture (IITA), Ibadan.

Nto P. O. O., \& Mbanasor J. A. (2009). Determinants of Credit Procurement among Rural Farmers in Abia State, Nigeria. Paper presented at the 43rd Annual Conference of Agricultural Society of Nigeria, 20th-23rd Oct. 2009, Abuja. Pp345-349

Nto P. O. O., \& Mbanasor J. A. (2011). Analysis of Determinants of Agribusiness Investment in a Young Economy: Nigeria (1999-2008). Journal of Social and Development Sciences, 2(3), 137-146.

Obamuyi T. M. (2007). An Exploratory Study of Loan Delinquency Among Small and Medium Enterprises in Ondo State of Nigeria. Labour and Management in Development Journal, 8.

Ogujiuba K. K, Oluche F. K., \& Achenuga A. O. (2004). Credit Availability to Small and Medium Scale Emterprises in Nigeria: Importance of New Capital for Banks-Background and issues. working paper.

Organisation for Economic Cooperation and Development OECD. (2006). Financing SMEs and Entrepreneurs. Policy Brief, OECD Observer, November.

Oyekanmi R. (2003). Concepts of Equity Financing and its Implications for SMIEIS. Seminar Paper on SMIEIS, Publication of CBN Training Centre, Lagos No.4.pp 61-80

Pedroni P. (2000). Fully Modified OLS for Heterogeneous Cointegrated Panels. Advances in Econometrics, 15, 92-130. http://dx.doi.org/10.1016/S0731-9053(00)15004-2

Peter C., \& B. Philips. (1995). Fully Modified Least Squares and Vector Autoregression. Econometrica, 63(5), 1023-1078.

Philips B., \& Hansen B. (1990). Statistical Inference in Instrumental Variables Regressions with 1(1) Process. Review of Economic Studies, 57, 99-125. http://dx.doi.org/10.2307/2297545

Philips B., \& Peter C. (1986). Understanding Spurious Regressions in Econometrics. Journal of Econometrics, 33, 311-340. http://dx.doi.org/10.1016/0304-4076(86)90001-1

Rahji, \& Apata. (2012). Understanding the Credit Supply Decisions of Banks under Small and Medium Enterprises Equity Investment Scheme (SMEEIS) in Nigeria. Download Internet Under www.google.com.

Rocha R., Farazi S., Khouri R., \& Pearce D. (2011). The Status of Bank Lending to SMEs in the Middle East and North African Region: The Result of a Joint Survey of the Union of Arab Banks and the World Bank. Financial Flagship, 1-45.

Udechukwu F. N. (2003). Survey of Small and Medium Scale Industries and Their Potentials in Nigeria. Seminar Paper on SMIEIS, 4, 1-14. Publication of CBN Training Centre, Lagos. 